\title{
GLYCAEMIC CONTROL AND AWARENESS AMONG DIABETIC PATIENTS OF NUTRITION RECOMMENDATIONS IN DIABETES
}

\author{
Karolina Ruszkiewicz ${ }^{1}$, Pawet Jagielski², Iwona Traczyk ${ }^{l}$ \\ ${ }^{1}$ Medical University of Warsaw, Faculty of Health Sciences, Department of Human Nutrition, Warsaw, Poland \\ ${ }^{2}$ Jagiellonian University Medical College, Faculty of Health Science, Department of Nutrition and Drug \\ Research, Cracow, Poland
}

\begin{abstract}
Background. The incidence of diabetes has been rising rapidly, especially in urbanized countries. It is estimated that by 2035 the number of diabetics will have increased to almost 600 million around the world. There is a substantial amount of evidence which points to proper education as one of the most effective ways of delaying the diabetes-related development of complications.

Objective. The aim of the study was to investigate the frequency of monitoring blood sugar by diabetic patients and their awareness of nutrition recommendations in diabetes.

Materials and methods. The study included 303 patients with type 1 and 2 diabetes. The research tool was a questionnaire based on the KomPAN questionnaire that consisted of a nutrition knowledge test and several questions concerning glycaemic control. The statistical analysis was carried out using the PS IMAGO PRO 5 (IBM SPSS Statistics 25) software. Results. Most of the patients demonstrated a medium level of knowledge $-62 \%$ of them provided $>50 \%$ of the correct answers. Only $8 \%$ of the respondents scored $>80 \%$ of the correct answers. Better test results were achieved by patients with type 1 diabetes. The highest percentage of correct answers was observed in the questions regarding the need to limit sweets or introduce fibre-rich whole-grain products $(>90 \%)$, the smallest percentage in the questions related to the assessment of carbohydrates and the glycaemic index of selected products $(<30 \%)$. The majority of the patients checked their blood sugar levels every day, but $6 \%$ of them gave up glucose measurements at home. About half of the respondents did not take the HbAlc test - the majority of them were patients with type 2 diabetes.

Conclusions. The level of knowledge of the examined patients was unsatisfactory and varied with the type of diabetes. Further education of patients about nutrition and glycaemic control is recommended.
\end{abstract}

Key words: diabetes, level of dietary knowledge, nutrition, glycaemic control

\section{STRESZCZENIE}

Wprowadzenie. Zapadalność na cukrzycę szybko wzrasta, szczególnie w krajach zurbanizowanych. Szacuje się, że w skali całego świata do 2035 r. liczba chorych na cukrzycę osiągnie poziom 600 milionów. Jest coraz więcej dowodów na to, że odpowiednia edukacja pacjentów jest jednym z najskuteczniejszych sposobów na opóźnienie rozwoju powikłań. Cel. Celem badań była ocena częstości wykonywania przez pacjentów pomiarów glikemii oraz ich wiedzy na temat zaleceń żywieniowych w cukrzycy.

Material i metody. Badanie objęło grupę 303 pacjentów z cukrzycą typu 1 i 2 . Narzędziem badawczym była autorska ankieta wzorowana na kwestionariuszu KomPAN, która składała się z testu wiedzy oraz pytań dotyczących samokontroli glikemii. Analizy statystycznej dokonano za pomocą programu PS IMAGO PRO 5 (IBM SPSS Statistics 25).

Wyniki. Większość pacjentów wykazała się średnim poziomem wiedzy żywieniowej - $62 \%$ z nich uzyskało $>50 \%$ poprawnych odpowiedzi. Jedynie $8 \%$ respondentów uzyskało wynik $>80 \%$ punktów. Lepsze wyniki z testu uzyskiwali pacjenci z cukrzycą typu 1. Najwyższy odsetek poprawnych odpowiedzi uzyskano w pytaniach o konieczność eliminowania słodyczy i wprowadzenia do diety bogatych $\mathrm{w}$ błonnik pełnoziarnistych produktów zbożowych $(>90 \%$ poprawnych odpowiedzi), a najniższy odsetek zaobserwowano w pytaniach wymagających oszacowania węglowodanów prostych i indeksu glikemicznego konkretnych produktów ( $<30 \%$ poprawnych odpowiedzi). Większość pacjentów wykonywała pomiar glikemii przynajmniej raz dziennie, jednak $6 \%$ zaniechało pomiarów domowych. Prawie połowa respondentów nie miała wykonywanego testu hemoglobiny glikowanej - większość tej grupy stanowili pacjenci z cukrzycą typu 2.

Wnioski. Poziom wiedzy badanych pacjentów był niezadowalający i różnił się w zależności od typu cukrzycy. Potrzebna jest dalsza edukacja pacjentów w zakresie żywienia i samokontroli glikemii.

Słowa kluczowe: cukrzyca, poziom wiedzy żywieniowej, sposób żywienia, kontrola glikemii

Corresponding author: Karolina Ruszkiewicz, Zakład Żywienia Człowieka, Wydział Nauki o Zdrowiu, Warszawski Uniwersytet Medyczny, ul. Erazma Ciołka 27, 01-445 Warszawa, e-mail: karolina.ruszkiewicz.26@gmail.com

(C) Copyright by the National Institute of Public Health - National Institute of Hygiene 


\section{INTRODUCTION}

Diabetes mellitus (DM) is a group of metabolic disorders that are characterized by a high blood glucose level. Around 3 million people in Poland and over 400 million worldwide suffer from diabetes $[3,11]$. It is estimated that by 2035 the number of diabetics will have increased to almost 600 million. In total, every 11 th person suffers from diabetes, and every second adult is not diagnosed [10].

An adequate nutrition education is an important element of therapy. Dieticians can help patients learn about the crucial issues related to the glycaemic index, the composition of meals, as well as adequate glycaemic control. The main goal of education is for the patients to obtain a normal blood glucose level as well as optimal serum lipid and lipoprotein levels, the optimal blood pressure and body weight [9].

The Polish Diabetes Association places particular emphasis on such nutritional aspects as: the intake of simple absorbable carbohydrates and trans fatty acids limited to a minimum, salt intake reduced to $5 \mathrm{~g}$ per day, daily dietary fibre intake increased to $25 \mathrm{~g} /$ day or $15 \mathrm{~g} / 1000 \mathrm{kcal}[14,16]$. Carbohydrates with a low glycaemic index and a low glycaemic load value are recommended, while saturated fats and products with reduced fibre content should be limited [12, 16]. A diet based on fresh vegetables and fruits, whole-grain cereals, legume seeds and nuts, with a limitation of fullfat dairy products significantly reduces the incidence of diabetes and allows better glycaemic control. The Mediterranean diet without calorie restrictions seems to be more effective in the prevention of diabetes than a low-fat diet [17].

An important aspect of diabetes management is glycaemic self-control, which should be exercised at least 4 times a day by patients who use multiple dose injection insulin therapy. Patients using oral hypoglycaemic drugs should perform a 4-point blood glucose profile once a week and one measurement at various times of the day [15].

The aim of the study was to assess diabetic patients' awareness of dietary recommendations in diabetes and the frequency of blood glucose self-monitoring.

\section{MATERIAL AND METHODS}

The study was conducted from November 2018 to March 2019 at three centers in Poland: 1) Brothers Hospitallers Hospital, Cracow, 2) Biomed Private Health Care Centre, Opole, and 3) Health Care Centre, Lidzbark Warmiński. The candidates for inclusion were patients with diabetes of type 1 or 2 , and aged over 15 . The results of the study were gathered into 2 sets reflecting the two groups of diabetics.
The data were collected using the author's questionnaire which consisted of metrics, questions about blood glucose self-control and a nutrition knowledge test. It was based on the KomPAN questionnaire [7]. The knowledge test contained 17 statements for which as many points could be scored. The level of knowledge was assessed as very good if $>80 \%$ of correct answers were provided, satisfactory with $30-80 \%$ of correct answers, and insufficient with a score of $<30 \%$ of correct answers.

The analyses and calculation of all the data were performed in the PS IMAGO PRO 5 (IBM SPSS Statistics 25) software, using the Mann-Whitney $\mathrm{U}$ test and Chi-square test. The level of statistical significance was set at $\mathrm{p}<0.05$

\section{RESULTS}

The study involved 303 patients aged 16 to 86 years, 197 of whom were females. The body mass index $(\mathrm{BMI})=$ body weight $(\mathrm{kg}) /$ height $(\mathrm{m})^{2}[20]$ was calculated according to the height and current body weight of the patients. The average BMI in the examined group was $27.6 \pm 4.89 \mathrm{~kg} / \mathrm{m}^{2}$. The characteristics of anthropometric features are presented in Table 1.

\section{Knowledge regarding diabetes}

Patients with type 1 diabetes scored more points than those with type 2 diabetes ( $10.26 \pm 2.4$ vs $8.58 \pm 3.4$, $\mathrm{p}<0.05)$. In the first group, the highest result obtained from the test was 15 points. The maximum number of points was scored by patients with diabetes of type 2 .

The analysis of the summary results from the knowledge test showed that only $8 \%$ of the patients had very good knowledge while $14.5 \%$ of them obtained less than $30 \%$ of the correct answers. Details of the test scores are shown in Table 2.

The majority of the patients knew that the consumption of certain products (sweets, honey, juices and fruit drinks) should be limited due to a high content of sugar. Most of the people knew that products with a low glycaemic index are recommended for diabetics. The greatest disparities in knowledge between the two groups appeared in the questions about the glycaemic index (GI). Especially patients with type 2 diabetes found it difficult to classify the GI of certain products (potatoes, cornflakes, bread, crisps). Only $26.1 \%$ of the patients knew that $0 \%$ fat products are not recommended to diabetics. Less than $50 \%$ of the respondents knew that dried fruits are recommended in diabetes and fructose should not be used as a sugar substitute. Table 3 presents the details of the respondents' knowledge of diet in diabetes.

It was also noted that patients with type 2 diabetes more often admitted in the test to the lack of knowledge about the topic. $45 \%$ of the patients with type 2 diabetes 
Table 1. Characteristics of the study group

\begin{tabular}{|c|c|c|c|c|}
\hline Variables & $\begin{array}{c}\text { Total } \\
(n=303)\end{array}$ & $\begin{array}{c}\text { Type } 1 \text { diabetes } \\
(n=125)\end{array}$ & $\begin{array}{c}\text { Type } 2 \text { diabetes } \\
(\mathrm{n}=178)\end{array}$ & p-value \\
\hline $\begin{array}{l}\text { Age [years] } \\
\mathrm{X} \pm \mathrm{SD} \\
\mathrm{Me} \\
\mathrm{Min} \\
\mathrm{Max}\end{array}$ & $\begin{array}{c}51.0 \pm 20.2 \\
56.0 \\
16.0 \\
86.0\end{array}$ & $\begin{array}{c}32.2 \pm 13.7 \\
29.0 \\
16.0 \\
63.0\end{array}$ & $\begin{array}{c}64.3 \pm 11.5 \\
64.0 \\
27.0 \\
86.0\end{array}$ & $<0.0001^{*}$ \\
\hline $\begin{array}{c}\text { Sex n }(\%) \\
\text { Women } \\
\text { Men }\end{array}$ & $\begin{array}{l}197(65.0) \\
106(35.0)\end{array}$ & $\begin{array}{l}97(77.6) \\
28(22.4)\end{array}$ & $\begin{array}{l}100(56.2) \\
78(43.6)\end{array}$ & $<0.0001 * *$ \\
\hline $\begin{array}{l}\text { BMI } \\
\qquad \begin{array}{l}\mathrm{X} \pm \mathrm{SD} \\
\mathrm{Me} \\
\mathrm{Min} \\
\mathrm{Max}\end{array}\end{array}$ & $\begin{array}{c}27.6 \pm 5.4 \\
27.6 \\
10.2 \\
47.6\end{array}$ & $\begin{array}{c}24.44 \pm 4.89 \\
23.6 \\
10.2 \\
46.6\end{array}$ & $\begin{array}{c}29.74 \pm 4.62 \\
29.4 \\
18.8 \\
47.6\end{array}$ & $<0.0001^{*}$ \\
\hline $\begin{array}{l}\text { Duration of disorder [years] } \\
\text { X } \pm \mathrm{SD} \\
\mathrm{Me} \\
\mathrm{Min} \\
\mathrm{Max}\end{array}$ & $\begin{array}{c}10.4 \pm 8.6 \\
8.0 \\
0.1 \\
43.0\end{array}$ & $\begin{array}{c}12.4 \pm 10.4 \\
11.0 \\
0.1 \\
43.0\end{array}$ & $\begin{array}{c}9.0 \pm 6.7 \\
7.0 \\
0.2 \\
30.0\end{array}$ & $<0.05^{*}$ \\
\hline
\end{tabular}

$\mathrm{n}$ - number of patients, $\mathrm{X}$ - average, $\mathrm{SD}$ - standard deviation, $\mathrm{Me}$ - median, Min - minimum value,

Max - maximum value, *Mann-Whitney $\mathrm{U}$ test, ${ }^{* *}$ Chi-squared test

Table 2. Percentage of patients with different knowledge levels depending on the type of diabetes

\begin{tabular}{|l|c|c|c|c|}
\hline \multicolumn{1}{|c|}{ Knowledge level } & $\begin{array}{c}\text { Total } \\
(\mathrm{n}=303) \\
\%\end{array}$ & $\begin{array}{c}\text { Type } 1 \\
\text { diabetes } \\
(\mathrm{n}=125) \\
\%\end{array}$ & $\begin{array}{c}\text { Type } 2 \\
\text { diabetes } \\
(\mathrm{n}=178) \\
\%\end{array}$ & $\mathrm{p}$-value \\
\hline Very good $(>80 \%$ correct answers) & 8.0 & 5.6 & 9.5 & $<0.05 *$ \\
\hline Satisfactory $(30-80 \%$ correct answers) & 77.5 & 89.6 & 69.1 \\
\hline Unsatisfactory $(<30 \%$ correct answers) & 14.5 & 4.8 & 21.4 \\
\hline
\end{tabular}

$\mathrm{n}$ - number of patients, $*$ Chi-squared test

Table 3. Percentage of correct answers depending on the type of diabetes

\begin{tabular}{|l|c|c|c|c|}
\hline \multicolumn{1}{|c|}{ Statement } & \multicolumn{3}{|c|}{ Correct answers } \\
\cline { 2 - 5 } & $\begin{array}{c}\text { Total } \\
(\mathrm{n}=303) \\
\%\end{array}$ & $\begin{array}{c}\text { Type } 1 \\
\text { diabetes } \\
(\mathrm{n}=125) \\
\%\end{array}$ & $\begin{array}{c}\text { Type } 2 \\
\text { diabetes } \\
(\mathrm{n}=178) \\
\%\end{array}$ & p-value* \\
\hline $\begin{array}{l}\text { Dietary protein and fats decrease postprandial } \\
\text { glycaemia }\end{array}$ & 20.8 & 18.4 & 22.5 & 0.3899 \\
\hline Fructose is a good sugar substitute & 48.5 & 56.8 & 42.7 & $\mathbf{0 . 0 1 5 6}$ \\
\hline GI of mashed potatoes < GI of jacket potatoes & 66.3 & 80.8 & 56.2 & $\mathbf{0 . 0 0 0 1}$ \\
\hline Dried fruits are recommended in diabetes & 47.8 & 37.6 & 55.0 & $\mathbf{0 . 0 0 2 7}$ \\
\hline $\begin{array}{l}\text { The need to reduce the consumption of sweets, } \\
\text { honey, juices and fruit drinks }\end{array}$ & 94.1 & 94.4 & 93.8 & 0.8335 \\
\hline Cornflakes have a low GI & 45.9 & 67.2 & 30.9 & $\mathbf{0 . 0 0 0 1}$ \\
\hline $\begin{array}{l}\text { The main source of carbohydrates should be } \\
\text { products with a low GI }\end{array}$ & 83.5 & 88.0 & 80.3 & 0.0769 \\
\hline Ripe bananas contain less sugar than apples & 61.4 & 69.7 & 55.6 & $\mathbf{0 . 0 1 3 9}$ \\
\hline $\begin{array}{l}\text { Resistant starch does not increase postprandial } \\
\text { glycaemia }\end{array}$ & 17.2 & 14.0 & 19.1 & 0.2853 \\
\hline
\end{tabular}




\begin{tabular}{|l|c|c|c|c|}
\hline $\begin{array}{l}\text { The need to replace light white bread with } \\
\text { whole wheat }\end{array}$ & 91.7 & 92.0 & 91.6 & 0.8942 \\
\hline Diabetics should eat a lot of cooked vegetables & 35.8 & 48.8 & 27.0 & $\mathbf{0 . 0 0 0 1}$ \\
\hline $\begin{array}{l}\text { 0\% fat products are not recommended to } \\
\text { diabetics }\end{array}$ & 26.1 & 40.0 & 16.3 & $\mathbf{0 . 0 0 0 1}$ \\
\hline Ketchup contains a lot of sugar & 58.7 & 67.2 & 52.8 & $\mathbf{0 . 0 1 2 2}$ \\
\hline $\begin{array}{l}\text { Raspberry tomatoes contain more sugar than } \\
\text { other varieties }\end{array}$ & 32.0 & 32.0 & 32.0 & 0.9967 \\
\hline $\begin{array}{l}\text { The amount and type of carbohydrates } \\
\text { consumed has an effect on glycaemia }\end{array}$ & 87.1 & 94.4 & 82.0 & $\mathbf{0 . 0 0 1 5}$ \\
\hline Wasa-type bread has a low GI & 41.2 & 35.9 & 44.4 & 0.1869 \\
\hline Crisps have a low GI & 69.3 & 88.0 & 56.2 & $\mathbf{0 . 0 0 0 1}$ \\
\hline
\end{tabular}

$\mathrm{n}$ - number of patients, *Chi-squared test

and $33.5 \%$ with type 1 diabetes marked the "hard to say" answer more than 4 times $(\mathrm{p}<0.05)$. Only $13.3 \%$ of all the respondents left this answer unmarked.

\section{Blood glucose self-monitoring}

As many as $50 \%$ of the patients declared that they had not been tested for HbAlc. This is shown in Table 4. The lack of blood glucose self-monitoring was more common among people with type 2 diabetes $(68 \%)$ than those with type 1 (22.4\%).

A vast majority of the patients checked their blood glucose level at home regularly. People with type 1 diabetes did it more often, i.e. 5.1 \pm 1.5 times a day, while patients with type 2 diabetes only $2.1 \pm 1.4$ times a day. Patients with type 1 diabetes had episodes of hypoglycaemia and hyperglycaemia more often than those with type 2 diabetes. The relevant values are, respectively: $(3.6 \pm 7.8$ vs $0.4 \pm 1.1, \mathrm{p}<0.05)$ for hypoglycaemia and $(13.0 \pm 41.2$ vs $1.9 \pm 12.2, \mathrm{p}<0.05)$ for hyperglycaemia.

Cases of complete abandonment of blood glucose self-monitoring were reported in both the groups under consideration. Such situations occurred more often among people with type 2 diabetes. Among 18 patients who did not take the measurement at all, only 5 declared that they had the HbAlc test. In two cases, the test results obtained a HbAlc target range between $5.4 \%$ and $6.5 \%$. In the remaining three cases the results ranged between 7.1 and $12.5 \%$.

Table 4. Glycaemic control among patients with type 1 and type 2 diabetes

\begin{tabular}{|c|c|c|c|c|c|c|c|}
\hline Variables & \multirow{2}{*}{\multicolumn{2}{|c|}{$\frac{\text { Total }}{(n=303)}$}} & \multirow{2}{*}{\multicolumn{2}{|c|}{$\frac{\text { Type } 1 \text { diabetes }}{(n=125)}$}} & \multirow{2}{*}{\multicolumn{2}{|c|}{$\begin{array}{c}\text { Type } 2 \text { diabetes } \\
(\mathrm{n}=178)\end{array}$}} & $\mathrm{p}$-value \\
\hline \multirow{2}{*}{ Did you take the HbA1c test? } & & & & & & & \multirow{4}{*}{$<0.05^{*}$} \\
\hline & $\mathbf{n}$ & $\%$ & $\mathbf{n}$ & $\%$ & $\mathbf{n}$ & $\%$ & \\
\hline Yes & 154 & 50.8 & 97 & 77.6 & 57 & 32.0 & \\
\hline No & 149 & 49.2 & 28 & 22.4 & 121 & 68.0 & \\
\hline Last $\mathrm{HbA1c}$ test result & \multicolumn{2}{|c|}{$(n=154)$} & \multicolumn{2}{|c|}{$(n=97)$} & \multicolumn{2}{|c|}{$(n=57)$} & \multirow{5}{*}{$<0.05^{* *}$} \\
\hline $\mathrm{X} \pm \mathrm{SD}$ & \multicolumn{2}{|c|}{$7.5 \pm 2.0$} & \multicolumn{2}{|c|}{$7.5 \pm 2.1$} & \multicolumn{2}{|c|}{$6.8 \pm 1.6$} & \\
\hline $\mathrm{Me}$ & \multicolumn{2}{|c|}{7.3} & \multicolumn{2}{|c|}{7.0} & \multicolumn{2}{|c|}{6.6} & \\
\hline Min & \multicolumn{2}{|c|}{4.2} & \multicolumn{2}{|c|}{5.2} & \multicolumn{2}{|c|}{4.2} & \\
\hline Max & \multicolumn{2}{|c|}{20.0} & \multicolumn{2}{|c|}{20.0} & \multicolumn{2}{|c|}{13.4} & \\
\hline \multirow{2}{*}{$\begin{array}{l}\text { Number of glucose } \\
\text { measurements per day }\end{array}$} & \multicolumn{2}{|c|}{$(n=303)$} & \multicolumn{2}{|c|}{$(n=125)$} & \multicolumn{2}{|c|}{$(n=178)$} & \multirow{9}{*}{$<0.05^{* *}$} \\
\hline & $\mathbf{n}$ & $\%$ & n & $\%$ & $\mathbf{n}$ & $\%$ & \\
\hline 0 & 18 & 5.9 & 2 & 1.6 & 16 & 9.0 & \\
\hline 1 & 59 & 19.5 & 5 & 4.0 & 54 & 30.4 & \\
\hline 2 & 59 & 19.5 & 4 & 3.4 & 55 & 30.9 & \\
\hline 3 & 33 & 10.8 & 11 & 8.8 & 21 & 11.8 & \\
\hline 4 & 24 & 7.8 & 6 & 4.8 & 18 & 10.1 & \\
\hline 5 & 30 & 9.9 & 20 & 16.0 & 10 & 5.6 & \\
\hline$\geq 6$ & 81 & 26.6 & 77 & 61.1 & 4 & 2.2 & \\
\hline
\end{tabular}

$\mathrm{n}$ - number of patients, HbAlc - glycated hemoglobin, X - average, SD - standard deviation,

$\mathrm{Me}-$ median, Min - minimum value, Max - maximum value, *Chi-squared test, **Mann-Whitney $\mathrm{U}$ test 


\section{DISCUSSION}

Adherence to dietary recommendations in diabetes is a very important element of therapy. However, only a conscious and properly educated patient will follow the recommendations. That is why continuing education is so important. The questionnaire allowed for checking the level of knowledge of the examined group.

The average percentage of the correct answers in our study was $54.5 \%$ and it was $13.5 \%$ higher than in Hotyńska's study [9]. The test results prove that the level of the patients' knowledge calls for further education. Although as many as $62 \%$ of them obtained $>50 \%$ of correct answers, only $8 \%$ scored $>80 \%$ of the points. A comparably low level of knowledge was demonstrated by Bronkowska's study [1], in which only $12 \%$ of the patients obtained a result of $>80 \%$ of correct answers. In Szypnicka and Sińska's study [18] only $34 \%$ of the respondents were able to correctly identify products rich in easily digestible carbohydrates. Bujko and Trzeciak [2] noticed that the knowledge of the principles of healthy nutrition among patients with type 2 diabetes was highly unsatisfactory, but it improved after they were subjected to instruction.

There are a number of studies which show that patients' knowledge depends on socioeconomic factors. Some researchers observed that the level of knowledge decreased with age [1,2], but increased with education and the duration of the disease $[1,2,13]$. In our study no such relationship was noted, which is consistent with the results of Glińska and Kubańska [8].

While assessing the knowledge part, we found that only a small percentage of the patients were able to estimate the glycaemic index or sugar content of the indicated products. Poor knowledge of the glycaemic index issue was also found in other studies [6,9]. Some of the questions contained in our knowledge test turned out to be much more problematic for respondents with type 2 diabetes, and others for the group with type 1 diabetes. About $80 \%$ of the patients with type 1 diabetes and $56 \%$ with type $2 \mathrm{knew}$ that jacket potatoes have a lower glycaemic index than peeled potatoes. Divergent answers were obtained to the question about recommendations in the consumption of dried fruit. $62 \%$ of the patients with type 1 diabetes and less than $25 \%$ of those with type 2 claimed that such products could be consumed.

By self-control we mean all those activities and decisions with which patients can control their illness on a daily basis. In the case of diabetic patients, selfmonitoring includes such activities as: watching and caring for the feet and weight, blood pressure control, proper insulin injection and the ability to modify its doses, as well as the self-monitoring of glucose using a glucometer [5].
Measuring the blood glucose level at home is one of the basic tests recommended in the care of diabetic patients. Self-monitoring turned out to be a breakthrough in the treatment of diabetes as it allowed patients to respond independently to hypoor hyperglycaemia. It has been shown that $71 \%$ of the patients with type 1 diabetes took measurements of glycaemia at least 3 times a day [19]. In our study, only $8.8 \%$ of the patients with type 1 diabetes had fewer than 3 blood glucose measurements per day. Others took a minimum of three measurements, and $61.6 \%$ of them did it six or more times a day.

On the other hand, in the group of people with type 2 diabetes, $61.3 \%$ of the respondents took $1-2$ measurements per day, which is in accordance with the recommendations of the Polish Diabetes Association [15]. Dudzińska [4] noted that after the implementation of insulin therapy patients with type 2 diabetes made their daily glycaemic measurements much more often $(73.1 \%)$ than before $(28.9 \%)$. However, there is a lack of comprehensive studies that would assess the frequency of glycaemic control among people with type 2 diabetes depending on the type of treatment.

Our own study also reported cases of complete abandonment of glycaemic self-control, which is difficult to explain by the patients' lack of knowledge due to the short duration of the disease. Only one person in this group suffered from diabetes less than a year, 7 people suffered $\leq 5$ years, another 4 patients $\leq 10$ years, and 6 of them struggled with diabetes for 16 to even 24 years. The lack of home glucose measurements taken by these patients may explain the absence of hypo- and hyperglycaemia declared in the questionnaire.

\section{CONCLUSIONS}

1. The nutrition test gave a true picture of the patients' knowledge of the recommendations for the treatment of diabetes. Only $8 \%$ of the patients showed a very good knowledge. Patients with type 1 diabetes secured better results than those with type 2 diabetes.

2. The majority of the patients checked their blood glucose level at home regularly. Most patients with type 1 diabetes took at least 5 measurements per day and people with type 2 diabetes 1-2 measurements.

3. Nearly half of the respondents have not been tested for HbAlc. This group predominantly included patients with type 2 diabetes.

4. Further education of patients on nutrition and glucose self-control is highly recommended.

\section{Conflict of interest}

The authors declare no conflict of interest. 


\section{REFERENCES}

1. Bronkowska M., Zatońska K., Orzel D., Biernat J.: Ocena wiedzy żywieniowej osób z cukrzycą typu 2 $\mathrm{w}$ świetle zaleceń dietetycznych [Evaluation of the nutritional knowledge of patients with type 2 diabetes in the light of dietary recommendations]. Bromat Chem Toksykol 2013; 4, 520-530 (in Polish).

2. Bujko J., Trzeciak K.: Ocena wiedzy żywieniowej u kobiet z cukrzycą typu $2 \mathrm{w}$ świetle zaleceń dietetycznych [Assessment of the nutritional knowledge of women with type 2 diabetes in the light of dietary recommendations]. Żyw Człow Metab 2004;31, 3:233246 (in Polish).

3. Cukrzyca, Ukryta Pandemia. Sytuacja w Polsce. Edycja 2014 [Diabetes: A hidden pandemic. The situation in Poland. Edition 2014 (in Polish). Available at http:// www.pfed.org.pl/aktualno347ci/cukrzyca-ukrytapandemia-2014 (Accessed 05.06.2019)

4. Dudzińska M., Tarach J.S., Malicka J., Zwolak A., Kowalczyk M., Nowakowski A.: Ocena zmian w zakresie samokontroli wśród pacjentów z cukrzycą typu 2 po wdrożeniu insulinoterapii - badanie prospektywne [Quality of life among patients with type 2 diabetes after insulin therapy introduction: A prospective study]. Fam Med Primary Care Rev 2013;15, 3:315-317 (in Polish).

5. Dziemidok P., Jaworska J., Cygan J.: Uwarunkowania wpływu samokontroli glikemii na wskaźniki wyrównania metabolicznego cukrzycy w praktyce ambulatoryjnej [Conditions influencing the efficacy of glycaemia self-control in out-patient care]. Med Metabol 2006;10, 4:1-6 (in Polish).

6. Gacek M., Chrzanowski M.: Zachowania żywieniowe mężczyzn w wieku 20-60 lat w świetle antropometrycznych wyników stanu odżywienia [Nutritional behaviours of men aged 20 to 60 in the light of the anthropometric indicators of nutritional status]. Rocz Państw Zakl Hig 2009;60(1):43-50 (in Polish).

7. Gawęcki J. (red.): Kwestionariusz do badania poglądów i zwyczajów żywieniowych oraz procedura opracowania danych [Dietary habits and nutrition beliefs questionnaire and the manual for developing nutritional data]. Zespół Behawioralnych Uwarunkowań Żywienia, Komitet Nauki o Żywieniu Człowieka Polskiej Akademii Nauk, Warszawa, 2014 (in Polish).

8. Glińska J., Kubańska E.: Ocena wiedzy i umiejętności oraz zapotrzebowania na edukację zdrowotną pacjentów z cukrzycą typu 2 [An assessment of diabetes 2 patients' knowledge and skills and of their demand for health education]. Ann Acad Med Lodz 2002;43, 4:5-9 (in Polish).

9. Hotyńska A., Kucharska A., Sińska B., Panczyk M.: Poziom wiedzy żywieniowej a sposób żywienia chorych na cukrzycę leczonych insuliną [The level of nutritional knowledge versus dietary habits of diabetes patients treated with insulin]. Pol Merk Lek 2015;39:233, 292296 (in Polish).

10. International Diabetes Federation Portal. Available at https://idf.org (Accessed 09.06.2019)

11. Kalbarczyk W.: Cukrzyca. Gdzie jesteśmy? Dokąd zmierzamy? [Diabetes. Where are we? Where are we heading?] Instytut Ochrony Zdrowia, Warszawa, 2018 (in Polish).

12.Klupa T: Dieta cukrzycowa jako element profilaktyki sercowo-naczyniowej [Diabetic diet as an element of cardio-vascular prevention]. Polskie Forum Profilaktyki Chorób Układu Krążenia (PFP) 2007;1, 6, 7 (in Polish).

13. Król E., Krejpcio Z., Troszok U.: Ocena poziomu wiedzy żywieniowej u pacjentów chorych na cukrzycę typu 2 [An assessment of the nutritional knowledge of type 2 diabetic patients]. Żyw Człow Metab 2007;34, 3-4:11271131 (in Polish).

14. Mędrela-Kuder E.: Prawidłowa dieta w cukrzycy typu 2 jako forma rehabilitacji chorych [Proper diet in type 2 diabetes as a means of patients' rehabilitation]. Rocz Panstw Zakl Hig 2011;62(2):219-223.

15. Polskie Towarzystwo Diabetologiczne, Zalecenia kliniczne dotyczące postępowania u chorych na cukrzycę 2019 [2019 Guidelines on the management of diabetic patients]. Diabetol Klin 2019;5, 1 (in Polish).

16. Rudnicka A.: Znaczenie diety w kontroli cukrzycy [The importance of diet in controlling diabetes]. Polskie Forum Profilaktyki Chorób Układu Krążenia (PFP), 2007; 1, 6, 7 (in Polish).

17. Salas-Salvadó J., Bulló M., Babio N., Ángel MartínezGonzález M., Ibarrola-Jurado N., Basora J., Etruch M., Covas M.I., Corella D., Arós F., Ruiz-Gutiérrez V., Ros $E$.: Reduction in the incidence of type 2 diabetes with the Mediterranean diet. Results of the PREDIMEDReus nutrition investigation randomized trial. Res Diabetes Care 2011;8, 1:21-28.

18. Szypnicka M., Sińska A.: Ocena wpływu wiedzy pacjentów o żywieniu na skuteczność leczenia dietetycznego w cukrzycy [Assessment of the influence of the patients' nutritional knowledge on the efficacy of dietary treatment in diabetes mellitus]. Med Metabol 2013;18, 3:35-40 (in Polish).

19. Trepińska M., Zozulińska D., Araszkiewicz A., WieruszWysocka B.: Ocena samokontroli glikemii u chorych na cukrzycę typu 1 leczonych metodą intensywnej czynnościowej insulinoterapii [Assessment of selfmonitoring of glycaemia in type 1 diabetic patients treated with functional insulin therapy]. Diabetol Prakt 2002; 3, 2: $69-73$ (in Polish).

20.World Health Organization Portal. Available at https:// euro.who.int (Accessed 24.03.2019)

Received: 02.03.2020

Accepted: 10.04 .2020 